\title{
Investigation of Salt Loss from the Bonneville Salt Flats, Northwestern Utah
}

James L. Mason and Kenneth L. Kipp, Jr.

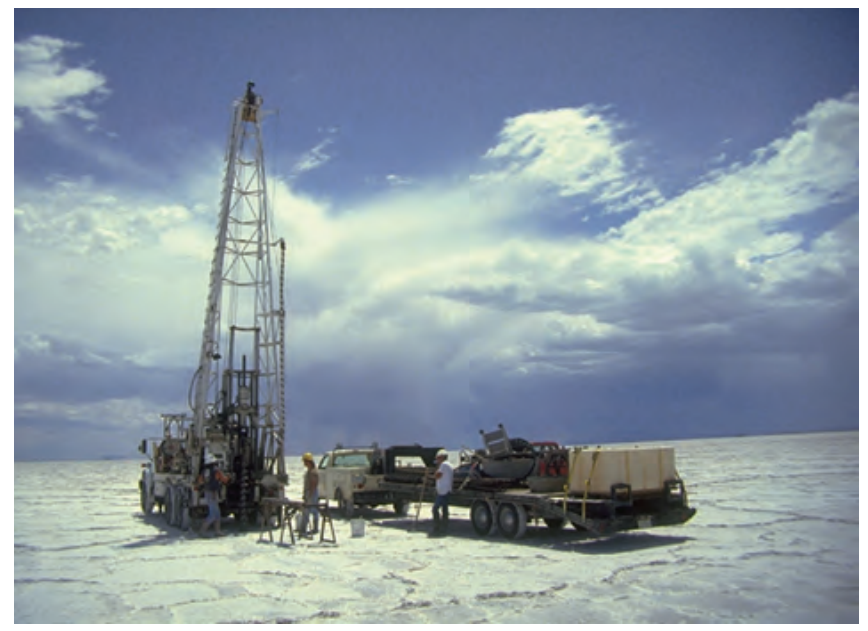

Drilling on the salt crust, Bonneville Salt Flats, Utah.

\section{Measurements of Salt Crust Indicate a Decrease in Thickness and Extent}

The Bonneville Salt Flats study area is located in the western part of the Great Salt Lake Desert in northwestern Utah, about 110 miles west of Salt Lake City (fig. 1). The salt crust covers about 50 square miles, but the extent varies yearly as a result of salt being dissolved by the formation and movement of surface ponds during the winter and redeposited with the evaporation of these ponds during the summer.

A decrease in thickness and extent of the salt crust on the Bonneville Salt Flats has been documented during 1960-88 (S. Brooks, Bureau of Land Management, written commun., 1989). Maximum salt-crust thickness was 7 feet in 1960 and 5.5 feet in 1988. No definitive data are available to identify and quantify the processes that cause salt loss. More than 55 million tons of salt are estimated to have been lost from the salt crust during the 28-year period. The Bureau of Land Management needs to know the causes of salt loss to make appropriate management decisions.

The salt crust has been used for high-speed automobile racing since 1914. The racing community has been concerned about the progressive deterioration of the racing surface. They have suggested that the issued. variable less decreasing thickness and extent of the salt crust are caused by brine withdrawal for mineral production.

\section{Mining of halite} (common table salt) from the Bonneville Salt Flats began in the early 1900s. Extraction of potash from brine beneath the Bonneville Salt Flats began in 1917, when supplies of potassium salts from Germany were interrupted during World War I. The area from which brine is withdrawn for potash production was expanded in 1963, when mineral leases on 25,000 acres of Federal land were

The Bonneville Salt Flats is a playa, which is a topographically low, flat area where evaporation is the only form of water loss from this arid

\section{EXPLANATION}

- 4210-Approximate potentiometric contourShows approximate altitude at which water level would have stood in tightly cased wells when referenced to an average density. Contour interval, in feet, is

- - Approximate location of ground-water divide Brine-collection ditch

Playa boundary

- Well-Shallow monitoring well completed to a depth of 25 feet or

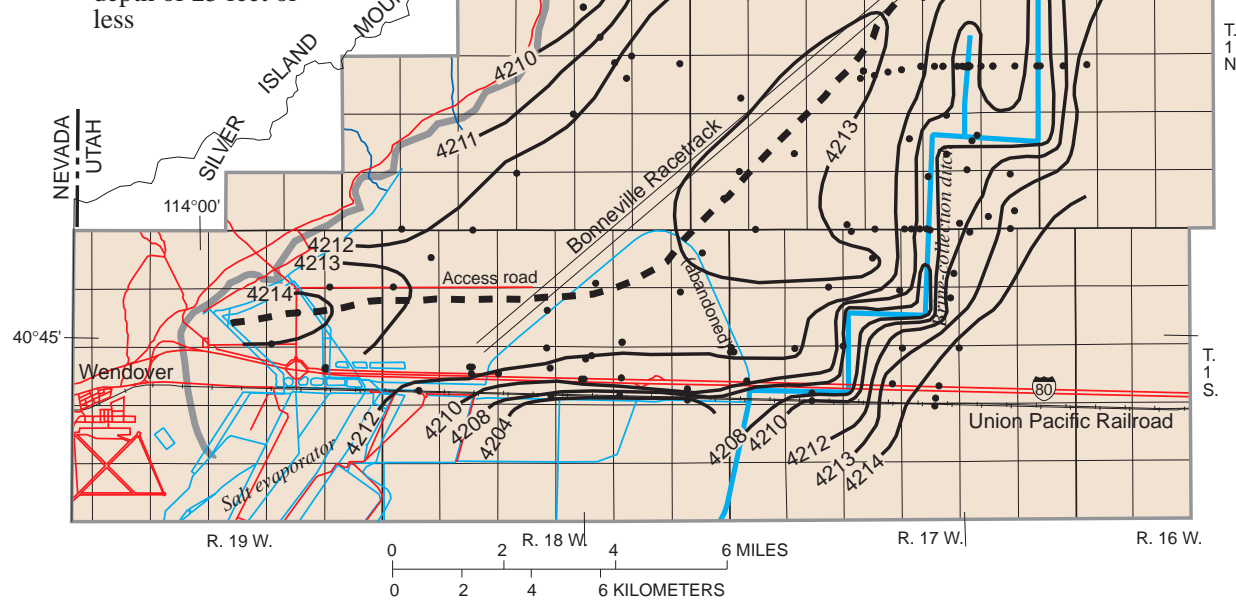

Figure 1. Water-table configuration based on an average density for September 1992 in the shallowbrine aquifer, Bonneville Salt Flats, Utah. region. The playa is flanked by the Silver Island Mountains on the northwest, and the land surface gradually slopes upward for many miles to the northeast, east, and south. Situated at the lowest altitude in the study area, the salt crust would be the final destination for surface runoff. Runoff from the flanks of the adjacent Silver Island Mountains generally occurs during intense summer thunderstorms and flows in distinct channels from the mountains toward the playa. These flows cross the alluvial fans but mostly disappear into large surface fractures before reaching the playa. Runoff during wetter-thannormal conditions can migrate several

(1)




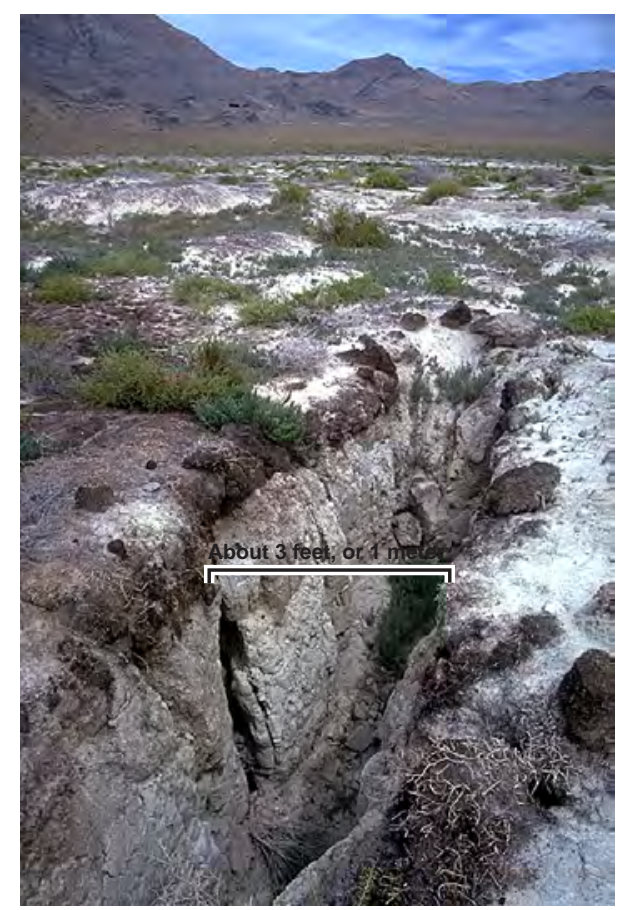

Large surface fracture in vegetation zone along northwestern margin of the playa. View is toward northwest, Silver Island Mountains in background.

miles from the northeast, east, and south. Slight changes in altitude of the land surface (less than 1 foot), however, can create small depressions where saline water can accumulate. Runoff toward the salt crust is sometimes impeded by these temporary storage depressions that are easily breached when the water level rises as a result of additional precipitation or when strong winds move sheets of water across the playa surface. Some of the runoff toward the salt crust is impeded by man-made structures such as the brine-collection ditch and associated berm located east of the salt crust, and the embankments created for Interstate Highway 80 and the railroad tracks to the south.

Ground water in the Bonneville Salt Flats study area is present in an alluvial-fan aquifer along the northwestern margin of the playa, in a deep

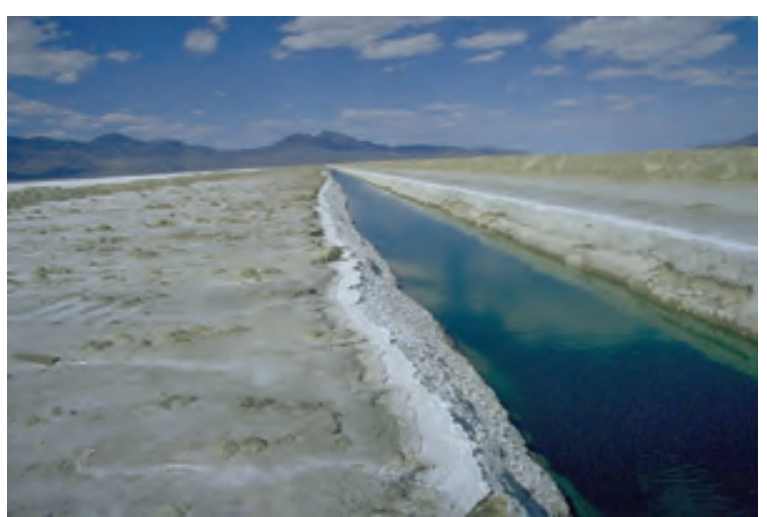

Brine-collection ditch, located east of the salt crust, Bonneville Salt Flats, Utah. basin-fill aquifer, and in a shallowbrine aquifer. Brine of economic value is present in the shallow-brine aquifer. Ground-water densities in the three aquifers vary from less-dense brackish water in the alluvial-fan aquifer to more-dense brines in the shallow-brine aquifer.

The shallow-brine aquifer is composed of a halite and gypsum crust at the surface and is surrounded by carbonate mud, both on the surface and immediately beneath the crust. Vertical fractures in the shallow-brine aquifer can be seen along the exposed sides of the brine-collection ditches and appear as salt ridges in a polygonal pattern on the salt-crust surface. These fractures, which can be up to an inch wide, are probably the principal conduits through which brine moves. The spacing between fractures varies; a 1-foot interval is common.

Previous studies of the hydrology of the Bonneville Salt Flats were done by Turk (1969) and Lines (1979). Data used by Turk were limited to areas adjacent to brine-collection ditches and evaporation ponds. Lines estimated the amount of brine and associated salt that flows into and out of the shallowbrine aquifer. The current study uses computer simulations of ground-water flow and transport of salt in solution in the shallow-brine aquifer to demonstrate salt and fluid movement within this dynamic ground-water system.

\section{Field Study and Computer Simulations Quantify Salt Loss}

This study was designed to define the hydrology of the ground-water system and its relation to the natural and human-induced processes causing salt loss. Specific topics of study included the transport of salt in solution by ground-water flow and the migration of ponded water. Data collected during this study were used to make hydrologic interpretations and to develop computer simulations to achieve a better understanding of the fluid and salt-transport processes in the shallow-brine aquifer.

Water-level and brinedensity data were used to contour the seasonal watertable surfaces of the shallowbrine aquifer. The water-table configuration (fig. 1)

represents conditions near the end of the evaporation season, after most of the brine used for mineral production has been withdrawn through the brinecollection ditches. The general configuration and altitude of the contours are very similar to those mapped by Lines (1979, fig. 35) for the same time of year. This comparison indicates that there is no long-term change in water levels within the shallow-brine aquifer despite seasonal and yearly fluctuations in fluid inflows and outflows. The horizontal movement of brine through the shallowbrine aquifer is from the center of the playa, where ground-water levels are high, toward the northwestern margin of the playa and toward the brinecollection ditches on the east and south, where water levels are low.

Water-level and density data collected at five locations during 1993, representative of wetter-than-normal conditions, indicate that a potential for downward movement existed between the shallow-brine aquifer and the underlying ancient Lake Bonneville sediment in the upper part of the basin-fill aquifer. Despite measurements that indicate downward movement, contradictory evidence indicates possible upward movement of brine in the area near the center of the salt crust.

Tritium values were determined for brine collected from several wells completed in the shallow-brine aquifer. Tritium is an unstable isotope of hydrogen that decays with a half-life of 12.3 years. The tritium value of ground water that is isolated from mixing with other water will decrease by one-half of its original value after 12.3 years. Tritium occurs naturally in the atmosphere, but the largest source was generated during atmospheric nuclear testing from 1952 to 1969. Present (1992-93) atmospheric tritium values are almost the same as those measured prior to atmospheric nuclear testing, about 10 tritium units. Tritium values measured in brine collected during this study range from 0 to 24 tritium units. Tritium values of about 10 tritium units measured in brine collected from the shallow-brine aquifer are indicative of water seeping into the subsurface within a few years prior to sampling. Tritium values of greater than about 10 tritium units are indicative of water seeping into the subsurface several years prior to sampling. Of greatest importance are tritium values of almost 0 tritium units measured in brine collected from the shallow-brine aquifer beneath the center of the salt crust. These values indicate mixing with older brine that 
has a tritium value of 0 tritium units. The only possible source for this brine is upward movement from the underlying lake sediment in the upper part of the basin-fill aquifer.

A comparison of water-chemistry data indicates that the dissolved-solids concentration in brine from the shallow-brine aquifer has not changed appreciably from 1976 to 1992. Despite the loss of salt by subsurface outflow to the brine-collection ditches, the high dissolved-solids concentration has been maintained primarily by dissolution of the salt crust and possibly by the addition of salt through upward movement of brine from the underlying lake sediment in the upper part of the basin-fill aquifer.

Recharge to the shallow-brine aquifer includes infiltration of rainfall from the playa surface and subsurface inflow from adjacent areas to the north and east. Infiltration of fresher water from the playa surface dissolves salt from the crust, whereas subsurface inflow from the north and east along with upward movement from the underlying lake sediment in the upper part of the basin-fill aquifer, if it occurs, transports salt into the shallow-brine aquifer. The amount of recharge by infiltration during 1992 was estimated to range from 8,300 to 12,900 acre-feet. One acre-foot of water is defined as 1 acre covered by 1 foot of water. Subsurface inflow from the north and east was estimated to be only 60 acre-feet.

Discharge from the shallow-brine aquifer primarily is by evaporation, which causes crystalline salt to precipitate on the playa surface. Additional discharge from the shallow-brine aquifer is by groundwater outflow to the south, primarily to a brine-collection ditch, and groundwater seepage to the brine-collection ditch east of the salt crust. Groundwater outflow to the adjacent alluvialfan aquifer along the northwestern margin of the playa and downward movement to the underlying lake sediment in the upper part of the basin-fill aquifer are relatively minor components. All subsurface outflows transport salt out of the shallow-brine aquifer in the study area. Evaporation from the shallow-brine aquifer in 1992 was estimated to be about 15,000 acrefeet. Estimated subsurface outflow to the south ranged from 1,800 to 2,300 acre-feet. Seepage to the brinecollection ditch east of the salt crust was estimated to be 1,500 acre-feet, more than double the 680 acre-feet reported by Lines (1979, p. 85).

Estimated downward leakage into the underlying lacustrine sediment ranged from 58 to 580 acre-feet, and subsurface outflow to the northwestern margin was about 40 acre-feet. Estimated salt loss through subsurface outflow from the shallow-brine aquifer was about 1.3 million tons.

Estimated discharge from $(18,400$ to 19,400 acre-feet) and recharge to $(8,300$ to 12,900 acre-feet) the shallow-brine aquifer during 1992 were considerably different. The difference is partly the result of uncertainty in values estimated for the hydrologic properties that describe the shallow-brine aquifer. Subsurface outflow to the south was estimated using water-level data collected in 1992 and transmissivity values determined prior to construction of Interstate Highway 80. Transmissivity is a measure of the capacity for water to pass through an aquifer. Removal of salt crust and compaction of underlying carbonate mud during highway construction probably resulted in a decrease in aquifer transmissivity, thereby decreasing discharge. Also, estimated recharge would be greater if the estimated storage capacity of the shallow-brine aquifer was larger and the amount of upward movement from the underlying lacustrine sediment was known.

In a ground-water flow system in which the density of the water varies within and between aquifers, the movement of ground water and the change in the solute concentration are closely related. The term solute, as used here, refers to salt dissolved in water. As the amount of dissolved salt increases, the density of the water also will increase. Changes in density cause changes in ground-water flow rates and direction. The only practical way to compute the flow of ground water

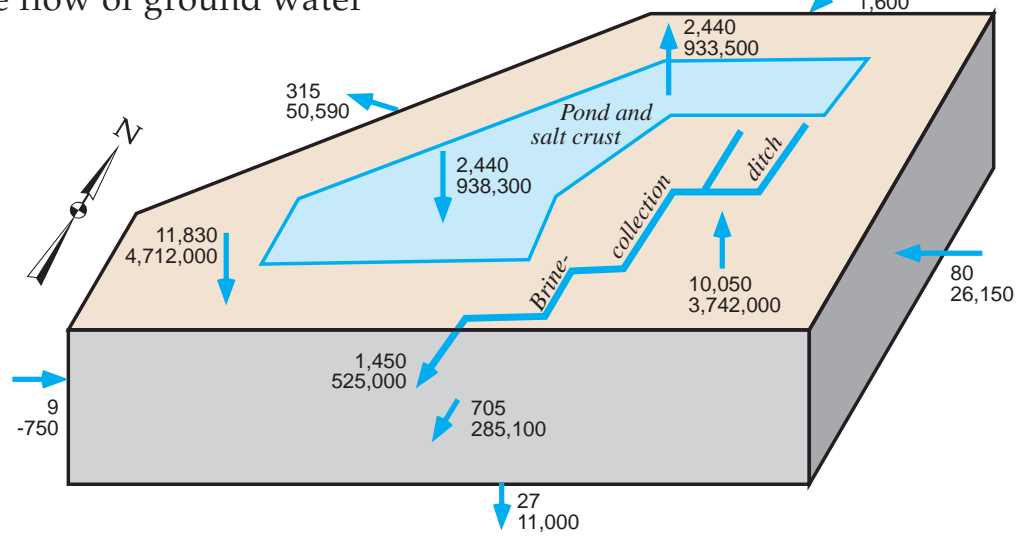

Figure 2. Generalized block diagram showing the simulated cumulative annual amounts of fluid (acre-feet, upper number) and solute (tons, lower number) moving into and out of the shallow-brine aquifer, Bonneville Salt Flats, Utah. with variable density is by computer simulation. The three-dimensional Heat and Solute Transport (HST3D) computer code (Kipp, in press) of the U.S. Geological Survey was used to simulate brine movement through the shallow-brine aquifer.

A seasonal sequence was simulated representing a typical 6-month summer-fall season of brine production and evaporation followed by a 6-month winter-spring season of water-table recovery and recharge. Insufficient data prevented the simulation of a specific time period and therefore, the approach was to simulate a typical climatic year with brine production from the brinecollection ditch east of the salt crust equal to the amount measured in 1992.

The goals of model simulations were to: (1) develop a fluid and solute balance for the shallow-brine aquifer, (2) evaluate the effect of brine production from the ditches on the salt crust, and (3) identify brine movement to and from the shallow-brine aquifer. These model simulations aid in understanding how brine production affects the gradual loss of salt from the crust.

The simulated fluid and solute amounts moving to and from the shallow-brine aquifer are shown in a generalized block diagram (fig. 2). To reasonably match measured water levels near Interstate Highway 80, transmissivity values were reduced to one-sixth of the previously estimated values reported by Lines (1979).

Simulated subsurface outflow to the south was about 700 acre-ft of fluid and 285,000 tons of solute, about onethird of the estimated amount for 1992 mentioned previously.

The sensitivity of the model simulations to uncertainties in the data 
were tested. Subsurface outflow of solute and the annual loss of crystalline salt was most sensitive to changes in the capacity of the shallowbrine aquifer to transmit brine near Interstate Highway 80. The annual loss of crystalline salt also was sensitive to the density of brine infiltrating from the playa surface. All sensitivity simulations resulted in a loss of crystalline salt during a typical year.

\section{Potential Loss of Salt from Crust by Flooding}

Extensive flooding on the playa surface during the winter and early spring of 1992-93 dramatically changed the salt surface. Much of the salt near the surface of the crust was dissolved and remained in solution into the summer of 1993. The salt eventually precipitated on the playa surface as the pond evaporated. A thin salt crust was deposited in areas beyond the extent of the crust that was mapped in 1992. Satellite imagery was used to determine the extent of the salt crust, which was 43 square miles in September 1992 and 58 square miles in August 1993 (fig. 3). The newly redeposited salt extended about 3 miles beyond the brine-collection ditch to the northeast. The amount of salt that was dissolved and subsequently redeposited on the playa surface or that was added to the shallow-brine aquifer in solution was estimated to be about 10 to 14 million tons. Some salt might have been deposited beyond topographic divides where it would not be able to join with the main salt body during subsequent dissolution and overland flow. The amount of salt, however, that might have been lost from the crust by this type of transport could not be determined. This extensive flooding, which also occurred during 1983-84, has the potential to transport millions of tons of salt beyond the salt-crust area.

\section{Loss of Salt from the Crust by Brine Withdrawal}

Model simulations, in which the 1992 rate of withdrawal from the brine-collection ditch east of the salt crust and average climatic conditions were used, indicate that brine withdrawal is a major cause of salt loss from the crust. Other than the cycling of fluid and solute through the playa surface each year, subsurface brine flow and solute transport to the brine-collection ditches east and south of the salt crust are the largest

\section{EXPLANATION}

Extent of salt crust, September 1992

Extent of salt crust, August 1993

Brine-collection ditch

Playa boundary
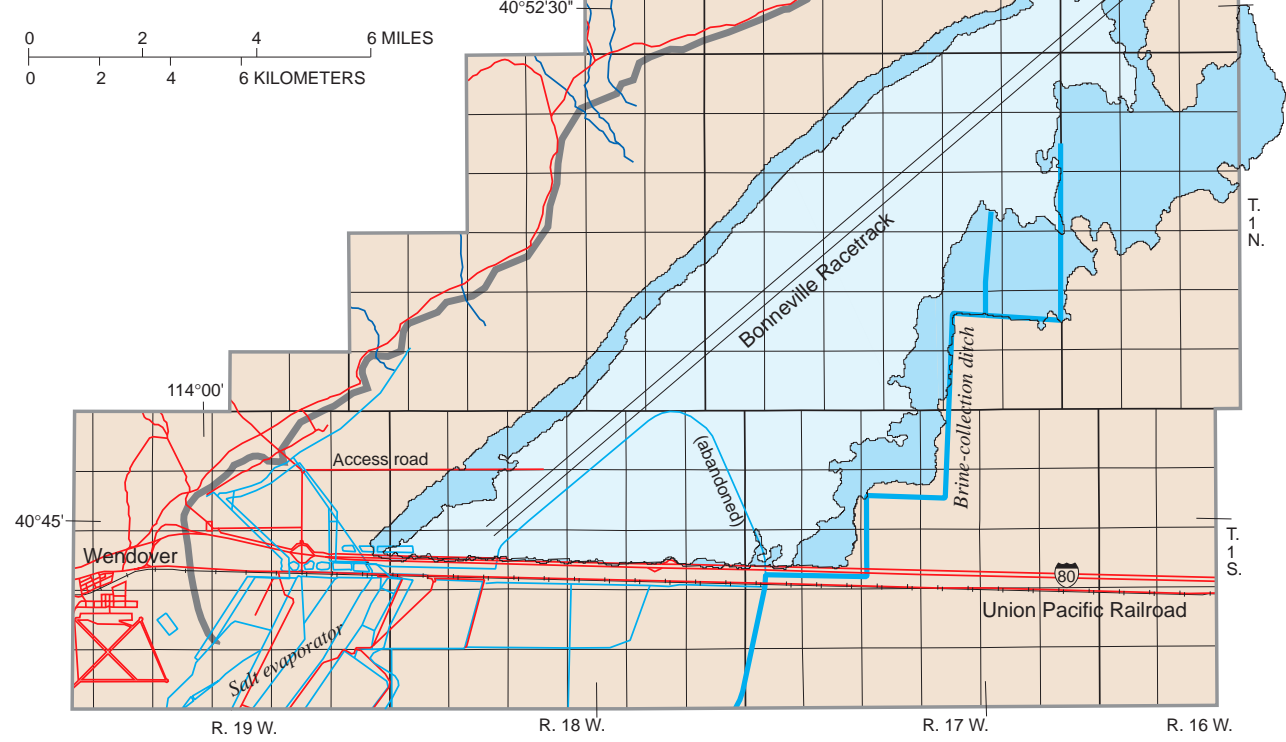

Figure 3. Increase in extent of salt crust from September 1992 to August 1993, Bonneville Salt Flats, Utah.

contributors to salt removal from the shallow-brine aquifer. Model simulations do not account for the occasional loss of salt from the crust by extensive flooding described previously.

On the basis of model simulations, the loss of crystalline salt from the playa surface is estimated to be about 975,000 tons per year. The concurrent subsurface loss of salt in solution was computed to be 850,000 tons per year. Uncertainties exist in the simulations because they were made from limited data, and these uncertainties contribute to simulation errors. The difference in computed loss of crystalline salt and salt transported through subsurface outflow of brine is within the acceptable simulation error.

\section{Selected References}

Bingham, C.P., 1980, Solar production of potash from brines of the Bonneville Salt Flats: in Gwynn, J.W., ed., Great Salt Lake, a Scientific, Historical and Economic Overview: Utah Geological and Mineral Survey Bulletin 16, p. 229243.

Kipp, Jr., K.L., in press, Guide to the revised heat and solute transport simulator: HST3D_-Version 2: U.S. Geological Survey Water-Resources Investigations Report 97-4157, 64 p.

Lines, G.C., 1979, Hydrology and surface morphology of the Bonneville Salt Flats and Pilot Valley playa, Utah: U.S. Geological Survey Water-Supply Paper 2057, 107 p.
Mason, J.L, Brothers, W.C., Gerner, L.J., and Muir, P. S., 1995, Selected hydrologic data for the Bonneville Salt Flats and Pilot Valley, western Utah, 1991-93: U.S. Geological Survey OpenFile Report 95-104, 56 p.

Mason, J.L., and Kipp. K.L., 1997, Hydrology of the Bonneville Salt Flats, northwestern Utah, and the simulation of ground-water flow and solute transport in the shallow-brine aquifer: U.S. Geological Survey Professional Paper 1585, 108 p.

Turk, L.J., 1969, Hydrology of the Bonneville Salt Flats, Utah: Unpublished PhD dissertation, Stanford University, 307 p.

\section{Sources of Additional Information}

Information on reports and hydrologic and other data related to the Bonneville Salt Flats can be obtained from:

U.S. Geological Survey Utah District

1745 West 1700 South

Salt Lake City, Utah 84104

(801) 975-3350

Bureau of Land Management

Salt Lake District

2370 South 2300 West

Salt Lake City, Utah 84119

(801) 977-4300

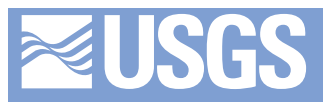

